\section{Military Technical College Kobry El-Kobbah, Cairo, Egypt.}

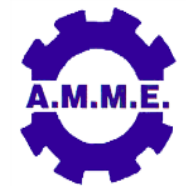

$18^{\text {th }}$ International Conference on Applied Mechanics and Mechanical Engineering.

\title{
GROWTH CONDITIONS OF THE ALGAE SPECIES BIOMASS IN A CONTINUOUS FEEDSTOCK PHOTO BIOREACTOR BY CONTROLLING THE SOLAR THERMAL RADIATION AND CLIMATE TEMPERATURE
}

\author{
E. A. El-Shenawy ${ }^{1}$, M. Elkelawy ${ }^{2}$, H. A. Bastawissi ${ }^{3}$ and M. Taha ${ }^{4}$
}

\begin{abstract}
Algae are one of the important sources of bio-diesel. Micro algae growth rate is directly affected by the sun light intensity and temperature. However, there is no available data in the literature concerning the environment temperature control to optimize the cultivate process of the algae in outdoor conditions. In the present study the outdoor continuous feedstock photo bioreactor has been designed and built to control the solar thermal radiation and its effect on the cultivation media temperature. Thos have been achieved using a new Air Bubble Generation (ABG) system. The used technique in the current study can enhance the temperature stability within the optimum range despite of the ambient conditions temperature. The results show that by increasing the air bubble generation rate the continuous photo bioreactor temperature distribution was enhanced along the reactor dimension. The optimum condition of the media $\mathrm{PH}$ is found to be $7.5, \mathrm{Na}_{2} \mathrm{CO}_{3}$ concentration of $5 \mathrm{~g}$, the media width of $25 \mathrm{Cm}$, media height of $25 \mathrm{Cm}$ and AWR (Air to Water Ratio by volume) of 150.
\end{abstract}

\section{KEY WORDS}

Solar Intensity, Microalgae Cultivation Control, Biodiesel Production, Biofuels, Algae, Photo bioreactor.

Prof., Mechanical Power Eng. Dept., Faculty of Engineering, Tanta Univ., Tanta, Egypt. Assoc. Prof., Mech. Power Eng. Dept., Faculty of Engineering, Tanta Univ., Tanta, Egypt, Email: medhatelkelawy@f-eng.tanta.edu.eg.

3 Dr. Eng., Mech. Power Eng. Dept., Faculty of Engineering, Tanta Univ., Tanta, Egypt.

4 Eng., Mechanical Power Eng. Dept., Faculty of Engineering, Tanta Univ., Tanta, Egypt. 


\section{INTRODUCTION}

Algae are one of the most important sources of bio-diesel nowadays [1-3]. Algae have a lot of advantages that make it participate with the different sources of biodiesel production [4-5]. Algae have higher ability of converting the sun energy into a liquid energy (Biodiesel).Biological treatment of water can be done by algae as it absorbs nitrogen and phosphorus [6-10].Algae can be produced in any lands and at any nature and fresh water is not necessary in cultivation process (it can use any kind of water even sea or brackish water).Algae production systems don't have specified shape or design and it can be adjustable as an open or close lop cycle. Algae can be harvested all over the year without seasonal production. Algae also have ability to absorb $\mathrm{CO}_{2}$ which helping in reducing greenhouse effect [11]. Algae have a lot of species that give us a wide range of choices which provide high production rate in different conditions (green, red and blue algae). It has short life cycle than any other type of bio-diesel source and it can be also used in cosmetics and pharmaceuticals industries and as a source of protein for animals feed [1213].The most important characteristics of algae biodiesel that it has higher calorific value, low viscosity, and low density that make it have diesel like properties in combustion process, in addition it is classified as renewable source or energy.

There are two main systems for harvesting and producing algae. The first technique is known as a race way pond system [14]. It is closed loop oval channel have $0.25: 0.40 \mathrm{~m}$ deep which open to air in which mechanical wheel is used for circulating the water and algae together. The main disadvantage of the race way pond system is the limits of system deep. Algal cells are shading each other when the depth of the media (water) is increased than a certain value. The second system is the Photo bioreactor (PBR) [15] which is defined as an array of closed transparent pipes connected to the main tank and opposed to the sun light all the daytime. Pure or brackish water electric pump is used in this system for circulating the media and algae from tank to pipes and vice versa. The main disadvantage of Photo BioReactor is being very expensive [16-18].

Controlling outdoor algae production systems is one of the hardest, complex and expensive operations due to the continuous change in the surroundings conditions over the daytime and over the actual life cycle of the algae. One of the most complex factors in algae biodiesel production is the sunlight intensity variation over the daytime and how to control its effect on the cultivation pond. Sunlight control system is aiming to increase the sunlight beam intensity as much as we can and decreasing the effect of the thermal radiation on the increasing the media of cultivation temperature [19-20].

According the previous research activity the best biomass productivity and lipid content have been recorded by Scenedesmus Obliquus green algae. However, the Scenedesmus Obliquus was chosen for this study to get the best biomass productivity [21-22]. Many investigates had been done to improve the Scenedesmus Obliquus green algae productivity. All the previous data suggested that the outdoor cultivation was the hardest method. It's difficult to control the thermal radiation of the sunlight and its effect on the media temperature in outdoor algae cultivation which will affect the biomass productivity. However, the weather conditions have been predicted in order to determine the day in which we can get the best productivity of the biomass for the outdoor Photo bioreactor [23]. 
In the present study, outdoor continuous feedstock photo bioreactor has been designed and built to control the solar thermal radiation and its effect on the algae cultivation temperature during the hours of the daylight. The system is designed to overcome the most difficulties of the algae biomass production by controlling the complex atmospheric conditions during the algae life cycle. This control method can adapt the system to the different conditions of climate change over the hours of the day sunlight. The designed system was adjusted to produce a tiny air bubbles inside the algae media to guarantee an easy crackdown of the heat energy to the surrounding air. The bubbles generation system can circulate the cultivation water, green algae, and the chemical components together during all day. However, the temperature distributions inside the bubbled glass boxes photo bioreactor were equalized even at different sunlight exposure during the day sunlight to all algae particles in the cultivation system. Also, the bubble generation system can increase the time of the algae exposure to sunlight [24-27]. The green alga exposure time to sunlight is enhances the transformation of sunlight energy transformation to biomass productivity.

\section{EXPERIMENTAL TEST-RIG AND PROCEDURE}

Experimental test rig should ensure a good and homogeneous flipping of algae and cultivation media (water) in the photobioreactor system. Guarantee a good sun exposure is also one of the most important fundamentals to be observed in the system. The availability of changing the height of media (water) has been considered during the designed system. The system can merge the characteristics of the common algae production systems, which are known as the race way pond system and tube photobioreactor. This production system enhances the sunlight utilization as in the pipe photobioreactor. However, less capital cost as in race way bond systems have been achieved with applying the closed loop automatic control system. To study the effect of photo bioreactor dimensions the different sizes of cultivation tanks have been designed. Three different tanks have been fabricated with fixed length of $75 \mathrm{~cm}$ and height of $45 \mathrm{~cm}$ and the width is changed to be 15,20 , and $25 \mathrm{~cm}$. The tanks are made from Acrylic (medium high impact) sheets, which promote better exposure to sunlight, with $10 \mathrm{~mm}$ thickness. Photo bioreactor system was set in Tanta city, Egypt (Latitude: $30^{\circ} 47^{\prime} 18^{\prime \prime} \mathrm{N}$, and Longitude: $31^{\circ} 00^{\prime} 06^{\prime \prime} \mathrm{E}$ ); they were put in a place, which ensures exposure to sunlight all day. The constructed test rig can be shown in Fig. 1.

There is a main cylindrical plastic tank have $60 \mathrm{~cm}$ diameter and $120 \mathrm{~cm}$ height. This tank is used to overcome the shortfall of water in the photo bioreactor tanks due to water evaporation and for the installation of separation unit. Separation unit consists of 2 Sieves with fine holes to separate algae from water to extract biodiesel from it. Two parallel centrifugal pumps are used for separating algae from the water and for emptying the system if required. Pumps also are used in mechanical flipping of system and to equalize the temperature in all system if needed.

Air compressor was used to supply air to the system. Air Rotameter is used to measure Air volume flow rate $(Q$ air) and 220 volts solenoid valve used to regulate the air entry to the system. Controlled electrical signal was used to open and close the solenoid which delivers air to Bubble Generation System (BGS) which consists of $8 \mathrm{~mm}$ copper pipes having $1 \mathrm{~mm}$ diameter holes at rate of 1hole every $6 \mathrm{~cm}^{2}$ as shown in Fig 2. Control system consists of two main sub systems in order to measure 
the system temperature and control the air solenoid valve. Temperature measuring system gives the signal to the controlled component to keep the system in the best operating conditions that allows the best production.

The first sub system consists of the Arduino Uno board and digital temperature sensor (DS18B20) installed so they can give a detailed Temperature sheet for the system every ten seconds. We can guarantee that if any change happens, the system will have a continuous feedback which allows fast processing of the changes to keep the system in balance. Second sub system consists of Arduino Uno board as a controller and relays connected to solenoids. Level switch is connected to the Arduino to give level feedback to the Arduino when water level decreases due to evaporation (about $4 \%$ of total water evaporated per day). Air quantity is defined by the air solenoid opening time which defined from the Arduino signal. Pumps are connected to the second sub system to control which function they will perform. Pumps functions are algae separation, flipping the system, equalize system temperature, and emptying the system. Flipping can be Intermittent depending on specific time plan to Save expense. Also, the separation can be performed automatically every completed life cycle. This control system guarantees full controlling the system and can be defined as automatic system. Emptying system is used in case of contamination of the system by any unwanted pollutants.

\section{Experimental Procedure}

\section{Laboratory experiments (Indoor examinations)}

Green algae S. Obliquus was developed in $250 \mathrm{ml}$ Erlenmeyer flasks containing 150 $\mathrm{ml}$ medium. The ways of life were lighted by tubular fluorescent lights with light intensity of $32 \mathrm{watt} / \mathrm{m}^{2}$.

\section{Outdoor experiments (Continuous Feedstock Photo bioreactor)}

Three different widths of the acrylic tanks were used to merge the advantages of race way bond and photo bioreactor. System is installed in a direct exposure to the sun light. Solar radiation, Water temperature, and compressed air flow rate were measured from 9 AM to 6 PM. (DS18B20) temperature sensor was used in the temperature measurements. Solar radiation was measured by EKO Pyranometer (MS-802). The uncertainties and the relative errors of the measurements are summarized in Table 1.

\section{RESULTS AND DISCUSSION}

The optimization process is divided into two parts, indoor and outdoor optimization. The first parts of the experiments were performed to get the optimum conditions for algae growth such as media salinity, $\mathrm{PH}$, and $\mathrm{Na}_{2} \mathrm{CO}_{3}$ concentration. This kind of the experiments have been done in laboratory in small scales. The second part is dealing with the outdoor optimization which is concerning the controlling on the solar thermal radiation and its effect on the cultivation temperature during the hours of the daylight. This kind of the experiment has been done in an outdoor continuous feedstock photo bioreactor.

\section{Indoor Experiments}

The impact of a variety of ph values [(ph control is7.5), (ph 6.5), (ph 5.5) and (ph 8.5)] 
on the development of S. Obliquus was recorded at O.D 680 for 18 days of brooding. (OD680) is the strategy in which the optical thickness of the way of life at $680 \mathrm{~nm}$ is utilized. The obtained results are available Fig. 4. It can be watched that, lessening or increment $\mathrm{PH}$ qualities prompted to decreases in the microalgae development.

The use of the various amount of $\mathrm{Na}_{2} \mathrm{CO}_{3}$ [control (0), 1, 3 and $5 \mathrm{~g}$ ] have been applied per liter of the cultivation media as a carbon source brought about the dynamic increment in algae growth, as shown in Fig. 5. It can be watched that, 1, 3 and $5 \mathrm{~g}$ of $\mathrm{Na}_{2} \mathrm{CO}_{3}$ empowered development by 9,26 , and $36 \%$, separately, as for control. The obtained data of the determination of the EFA substance of diversely treated cultures with $0,1,3$, and $5 \mathrm{~g} \mathrm{Na}_{2} \mathrm{CO}_{3}$ are displayed in Fig. 6. Utilization of 1 gof $\mathrm{Na} 2 \mathrm{CO} 3$ brought on acceptance in EFA content by $11 \%$ as for control. However, 3 and $5 \mathrm{~g}$ of induction were demonstrating a similar percent of increment in EFA content by $24 \%$ over the control. Because of incitement of development and EFA generation, the EFA efficiency expanded by expanding the centralization of acceptance. The expansion was recorded by 32,45 , and $53 \%$ over the control level at 1,3 and $5 \mathrm{~g}$ of $\mathrm{Na}_{2} \mathrm{CO}_{3}$ individually.

\section{Outdoor Experiments}

The ruling factor in outdoor algae cultivation is temperature. To obtain optimum green algae productivity the cultivation conditions of temperature, salinity, and $\mathrm{Na}_{2} \mathrm{CO}_{3}$ concentration must be also optimized.

In order to ensure the optimum green algae productivity the outdoor cultivation system must be arranged at certain value of media temperature of $35{ }^{\circ} \mathrm{C}$. Also, the media salinity and $\mathrm{Na}_{2} \mathrm{CO}_{3}$ concentration requires a positive control on its values. Outdoor experiments were made to shorten the time of water temperature that is higher than $35^{\circ} \mathrm{c}$.Due to the different atmospheric conditions the Temperature fracture used to compare the heights and choose the best of them. Temperature fracture is the period in which the temperature is higher than $35^{\circ} \mathrm{c}$ to the time in which the temperature of the surroundings is higher than $35^{\circ} \mathrm{c}$. Outdoor experiments were done in a specific sequence to get the optimum operating conditions of tank width, water height, cooling compressed air quantity and using mechanical circulation or not as showed in Table 2.

\section{Optimum width}

This test is done using widths of 15,20 and $25 \mathrm{~cm}$ with solar intensity distribution as shown in Fig. 7. The mean average value of IR is $666.25 \mathrm{~W} / \mathrm{m}^{2}$ for all-day of experiment. The maximum recorded value was $915 \mathrm{~W} / \mathrm{m}^{2}$.

Figure 8 shows the temperature variation in tanks and the effect of width in temperature distribution. For the minimum width of $15 \mathrm{~cm}$ the water temperature reaches its peak and stay around this peak value the longest time then the curve starts descending. The width of $25 \mathrm{~cm}$ reaches its peak value last this peak value is the least of three cases. The $20 \mathrm{~cm}$ width acts between 15 and 25 widths with an intermediate behavior. Width of $25 \mathrm{~cm}$ is the maximum allowable width due to algae shading in higher widths. 


\section{Optimum medium height}

Three heights $(15 \mathrm{~cm}, 20 \mathrm{~cm}$, and25 $\mathrm{cm}$ ) were experimented to choose the optimum height 15, 20, $25 \mathrm{Cm}$. $25 \mathrm{Cm}$ height is maximum allowable height due to algae self shading. Solar intensity is almost constant during the measuring days in the three heights as shown in Fig 9. The max recorded. Solar intensities in range of 915 to 930 $\mathrm{W} / \mathrm{m}^{2}$ and the mean average value all the days of study were about $670 \mathrm{~W} / \mathrm{m}^{2}$.

\section{a) Media height of $15 \mathrm{Cm}$}

The max obtained day temperature in the cycle was chosen for illustrating the effect of height variation. The day of $46.5^{\circ} \mathrm{C}$ max recorded temperature was chosen for 15 $\mathrm{cm}$ height. The behavior of the system didn't change all over the mini cycle. We noted that the temperature fracture is (1.0061) as shown in Fig. 10. It's observed in this case that the productivity became $\left(0.3821 \mathrm{gm}^{-\mathrm{L}^{-1}}\right.$.Day $\left.{ }^{-1}\right)$.

\section{b) Media height of $20 \mathrm{Cm}$}

The max obtained day temperature in the cycle was chosen for illustrating the effect of height variation. The day of $45^{\circ} \mathrm{C}$ max recorded temperature was chosen for $20 \mathrm{~cm}$ height. The behavior of the system didn't change all over the mini cycle. We noted that the temperature fracture is (0.917782) as shown in Fig. 11. It's observed in this case that the productivity became $\left(0.3874 \mathrm{gm}^{-1} \mathrm{~L}^{-1}\right.$.Day $\left.{ }^{-1}\right)$.

\section{c) Media height of $25 \mathrm{Cm}$}

The max obtained day temperature in the cycle was chosen for illustrating the effect of height variation. The day of $43.6^{\circ} \mathrm{C}$ max recorded temperature was chosen for 25 $\mathrm{cm}$ height. The behavior of the system didn't change all over the mini cycle. We noted that the temperature fracture is $(0.905222)$ as shown in Fig. 11. It's observed in this case that the productivity became $\left(0.4189 \mathrm{gm}^{-\mathrm{L}^{-1}}\right.$.Day $\left.{ }^{-1}\right)$.

\section{Effect of flipping the medium using pumps}

This test is done in two cases which are, flipping in all the day and flipping half day. Solar intensity is almost constant during the measuring days in the two cases. As shown in Fig. 13, the max recorded solar intensities in range of 920 to $930 \mathrm{~W} / \mathrm{m}^{2}$ and the mean average value of solar intensity all the days of study was about $670 \mathrm{~W} / \mathrm{m}^{2}$.

\section{a) Flipping the medium using pumps all the day}

Media height of $25 \mathrm{~cm}$ was chosen for the study and centrifugal pumps were used in flipping the system. Previous studies show that flipping media is enhancing the productivity. First case we use pumps in flipping all day with a working rate of 10 minutes on and $10 \mathrm{~min}$ off. Using pumps made the temperature to be high quickly which is negative effect besides the positive effect of flipping in enhancing the productivity. The max obtained day temperature in the cycle was chosen for illustrating the effect of Flipping the medium using pumps all day. The day of $47.4^{\circ} \mathrm{C}$ max recorded temperature was chosen. The behavior of the system didn't change all over the mini cycle. We noted that the temperature fracture is $(0.923893)$ as shown in Fig. 14. It's observed in this case that the productivity became $\left(0.3230 \mathrm{gm}^{-1} \mathrm{~L}^{-1}\right.$. Day $\left.{ }^{1}\right)$. Pump has positive effect in the second half of the day as it helps in decreasing system temperature rapidly than the ordinary one that which will be studied in the next case. 


\section{b) Pump flipping half the day}

This case we took the positive effect of the pumps which happened in the second half of day that helps in decreasing the system temperature. Pumps have been used in the same previous rate $10 \mathrm{mins}$ on and $10 \mathrm{mins}$ off but this time they started working at 2:00 PM to allow the system curves to descend with surrounding curve. The max obtained day temperature in the cycle was chosen for illustrating the effect of flipping the medium using pumps half the day. The day of $45.5^{\circ} \mathrm{C}$ max recorded temperature was chosen. The behavior of the system didn't change all over the mini cycle. We noted that the temperature fracture is $(0.818182)$ as shown in Fig. 15. It's observed in this case that the productivity became $\left(0.4192 \mathrm{gm}^{-\mathrm{L}^{-1}}\right.$. Day $\left.{ }^{-1}\right)$.

The optimum is not using pumps because the productivity has no significant increase or increased at very small value relative to pump power consumption.

\section{Effect of using Air Bubble Generation in flipping and cooling the system}

Compressed air was used in Bubble Generation System for two main purposes are media flipping and cooling system by decreasing heat transfer from surroundings to water. Air was inserted to media according to AWR (Air Water Ratio) which is air volume during day to the water volume in system. Two main ratios were used 100and 150 AWR. Fixed flow rate of air of $90 \mathrm{~L} / \mathrm{Min}$. The total amount of air entering the system was defined by the opening times of the air solenoid and the intervals between openings. Solar intensity is almost constant during the measuring days in the two cases bas shown in Fig. 16. The max recorded solar intensities in range of 940 to $948 \mathrm{~W} / \mathrm{m}^{2}$ and the mean average value all the days of study was about 672 $\mathrm{W} / \mathrm{m}^{2}$.

\section{a) Effect of air bubble generation system of 100 AWR}

Fixed flow rate of 90 LPM was used with solenoid opening for 66 seconds and closing time for 254 seconds that allows for $11.25 \mathrm{~m} 3$ (AWR of 100) of compressed air to enter the system through bubble generation system. The max obtained day temperature in the cycle was chosen for illustrating the effect of using air bubble generation system. The day of $46.3^{\circ} \mathrm{C}$ max recorded temperature was chosen. The behavior of the system didn't change all over the mini cycle. We noted that the temperature fracture is $(0.708185)$ as shown in Fig. 17. It's observed in this case that the productivity became $\left(0.6249 \mathrm{gm} . \mathrm{L}^{-1}\right.$. Day $\left.{ }^{-1}\right)$.

\section{b) Compressed air in flipping and cooling the system of 150 AWR}

Fixed flow rate of 90 LPM was used with solenoid opening for 90 seconds and closing time for 230 seconds that allows for $16.8 \mathrm{m3}$ (AWR of 150) of compressed air to enter the system through bubble generation system. The max obtained day temperature in the cycle was chosen for illustrating the effect of using air bubble generation system. The day of $45^{\circ} \mathrm{C}$ max recorded temperature was chosen. The behavior of the system didn't change all over the mini cycle. We noted that the temperature fracture is $(0.605556)$ as shown in Fig. 18. It's observed in this case that the productivity became $\left(0.7561 \mathrm{gm}^{-\mathrm{L}^{-1}}\right.$. Day $\left.{ }^{-1}\right)$.

Table 3 and Fig. 19 are showing the different productivties of all tested cases. 


\section{CONCLUSION}

Experiments work have been conducted to study the effect of various operating and designe conditions on the photo bioreactor system to obtain the optimal gree algae productivety. However, the main conclusion are sumarized as follow:

- Generally, for all cases of the study the value of temperature of water decrease by increasing the width of the tank until a specified limit of $25 \mathrm{~cm}$ to avoid the shading of the alagal cells.

- Increasing the height of the water level decreases the time of being on temperature higher than $35^{\circ} \mathrm{C}$ of the system to the time in which surroundings be in higher than $35^{\circ} \mathrm{C}$.

- Using mechanical pump circulating all the day make it worse it inhanced heat transfer and inreased the time of being in deadly temperature so the production decreased and become the less productivity rate.

- Using the half day flipping helps in exploiting the positive effect of the pump flipping and ignoring the negative effect and also we made agreat benefits of flipping it self. All of the above things had involved a clear participation in improving productivity but still very small improving Compared to its cost.

- Using the compressed air in it's two cases had made an obvious improvement in produtivity and from experiments increasing air quantity increases the productivity and enhances the type of producted bio mass.

- Optimum $\mathrm{PH}$ is 7.5 and $\mathrm{Na} 2 \mathrm{CO} 3$ concentration of $5 \mathrm{~g}$.

- Optimum tank width is $25 \mathrm{Cm}$ and water height of $25 \mathrm{Cm}$ with no mechanical circulating.

- Optimum Air to water ratio is 150 for more AWR the benefits are less than coasts.

\section{ACKNOWLEDGMENT}

This work was supported by the Tanta University Research Fund under the research grant (code: cod-tu; 03-15-02).

\section{REFERENCES}

[1] Brennan, L. And P. Owende, Biofuels from microalgae - a review of technologies for production, processing, and extractions of biofuels and coproducts. Renewable and sustainable energy reviews, 2010. 14(2): p. 557-577.

[2] Khan, S.A., et al., Prospects of biodiesel production from microalgae in India. Renewable and sustainable energy reviews, 2009. 13(9): p. 2361-2372.

[3] Demirbas, A. And M.F. Demirbas, Importance of algae oil as a source of biodiesel. Energy Conversion and Management, 2011. 52(1): p. 163-170.

[4] Ahmad, A., et al., Microalgae as a sustainable energy source for biodiesel production: a review. Renewable and sustainable energy reviews, 2011. 15(1): p. 584-593.

[5] Kumar, S., D. Sahoo, and I.A. Levine, Algae as a Source of Biofuel, in The Algae World2015, Springer. P. 483-500.

[6] Aslan, S. And I.K. Kapdan, Batch kinetics of nitrogen and phosphorus removal from synthetic wastewater by algae. Ecological Engineering, 2006. 28(1): p. 6470. 
[7] Munoz, R. And B. Guieysse, Algal-bacterial processes for the treatment of hazardous contaminants: a review. Water research, 2006. 40(15): p. 27992815.

[8] Hoffmann, J.P., Wastewater treatment with suspended and nonsuspended algae. Journal of Phycology, 1998. 34(5): p. 757-763.

[9] Lau, P., N. Tam, and Y. Wong, Effect of algal density on nutrient removal from primary settled wastewater. Environmental Pollution, 1995. 89(1): p. 59-66.

[10] Duy, T.N., et al., Toxicology and risk assessment of freshwater cyanobacterial (blue-green algal) toxins in water, in Reviews of Environmental Contamination and Toxicology2000, Springer. P. 113-185.

[11] Brune, D., T. Lundquist, and J. Benemann, Microalgal biomass for greenhouse gas reductions: potential for replacement of fossil fuels and animal feeds. Journal of Environmental Engineering, 2009. 135(11): p. 1136-1144.

[12] Mata, T.M., A.A. Martins, and N.S. Caetano, Microalgae for biodiesel production and other applications: a review. Renewable and sustainable energy reviews, 2010. 14(1): p. 217-232.

[13] Skjånes, K., C. Rebours, and P. Lindblad, Potential for green microalgae to produce hydrogen, pharmaceuticals and other high value products in a combined process. Critical reviews in biotechnology, 2013. 33(2): p. 172-215.

[14] Chiaramonti, D., et al., Review of energy balance in raceway ponds for microalgae cultivation: re-thinking a traditional system is possible. Applied Energy, 2013. 102: p. 101-111.

[15] Pulz, O., Photobioreactors: production systems for phototrophic microorganisms. Applied microbiology and biotechnology, 2001. 57(3): p. 287293.

[16] Jorquera, O., et al., Comparative energy life-cycle analyses of microalgal biomass production in open ponds and photobioreactors. Bioresource technology, 2010. 101(4): p. 1406-1413.

[17] Sforza, E., M. Enzo, and A. Bertucco, Design of microalgal biomass production in a continuous photobioreactor: an integrated experimental and modeling approach. Chemical Engineering Research and Design, 2014. 92(6): p. 11531162.

[18] Richardson, J.W., M.D. Johnson, and J.L. Outlaw, Economic comparison of open pond raceways to photo bio-reactors for profitable production of algae for transportation fuels in the Southwest. Algal Research, 2012. 1(1): p. 93-100.

[19] Singh, S. And P. Singh, Effect of temperature and light on the growth of algae species: a review. Renewable and sustainable energy reviews, 2015. 50: p. 431-444.

[20] Cassidy, K.O., Evaluating algal growth at different temperatures. 2011.

[21] Álvarez-Díaz, P., et al., Freshwater microalgae selection for simultaneous wastewater nutrient removal and lipid production. Algal Research, 2017.

[22] Mandal, S. And N. Mallick, Microalga Scenedesmus obliquus as a potential source for biodiesel production. Applied microbiology and biotechnology, 2009. 84(2): p. 281-291.

[23] De-Luca, R., et al., Exploiting meteorological forecasts for the optimal operation of algal ponds. Journal of Process Control, 2017. 55: p. 55-65.

[24] Sorokin, C. And R.W. Krauss, The Effects of Light Intensity on the Growth Rates of Green Algae. Plant physiology, 1958. 33(2): p. 109.

[25] King, R. And W. Schramm, Photosynthetic rates of benthic marine algae in relation to light intensity and seasonal variations. Marine Biology, 1976. 37(3): p. 215-222. 
[26] Brown, T.E. and F.L. Richardson, The effect of growth environment on the physiology of algae: light intensity. Journal of Phycology, 1968. 4(1): p. 38-54.

[27] Foy, R., C. Gibson, and R. Smith, The influence of daylength, light intensity and temperature on the growth rates of planktonic blue-green algae. British phycological journal, 1976.11(2): p. 151-163. 
Figures and Tables:

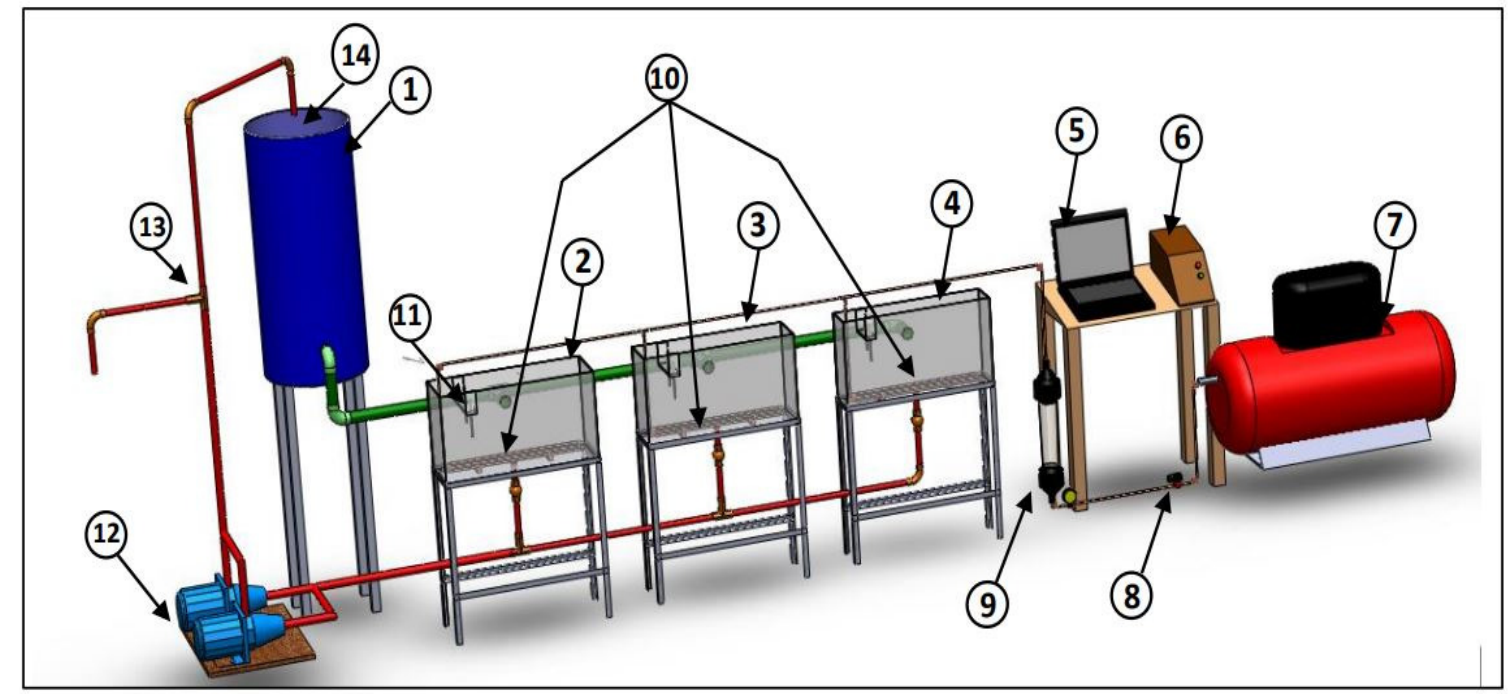

\begin{tabular}{|c|l|c|l|}
\hline No. & Component & No. & Component \\
\hline $\mathbf{1}$ & Main tank & $\mathbf{8}$ & Air solenoid valve \\
\hline $\mathbf{2}$ & $25 \mathrm{~cm}$ width tank & $\mathbf{9}$ & Air measuring device (Rotameter) \\
\hline $\mathbf{3}$ & $20 \mathrm{~cm}$ width tank & $\mathbf{1 0}$ & Air bubbles generation system (BGS) \\
\hline $\mathbf{4}$ & $15 \mathrm{~cm}$ width tank & $\mathbf{1 1}$ & Temperature measuring set \\
\hline $\mathbf{5}$ & Computer device & $\mathbf{1 2}$ & Centrifugal pumps \\
\hline $\mathbf{6}$ & Control system & $\mathbf{1 3}$ & Water direction changer (WDC) \\
\hline $\mathbf{7}$ & Air compressor & $\mathbf{1 4}$ & Algae separation system \\
\hline
\end{tabular}

Fig. 1. Test rig layout with the main components.

\section{1-Air vents}

2-Air flowrate measuring (rotameter)

3-Pressure gauge

4-Air solenoid

5-Air compressor

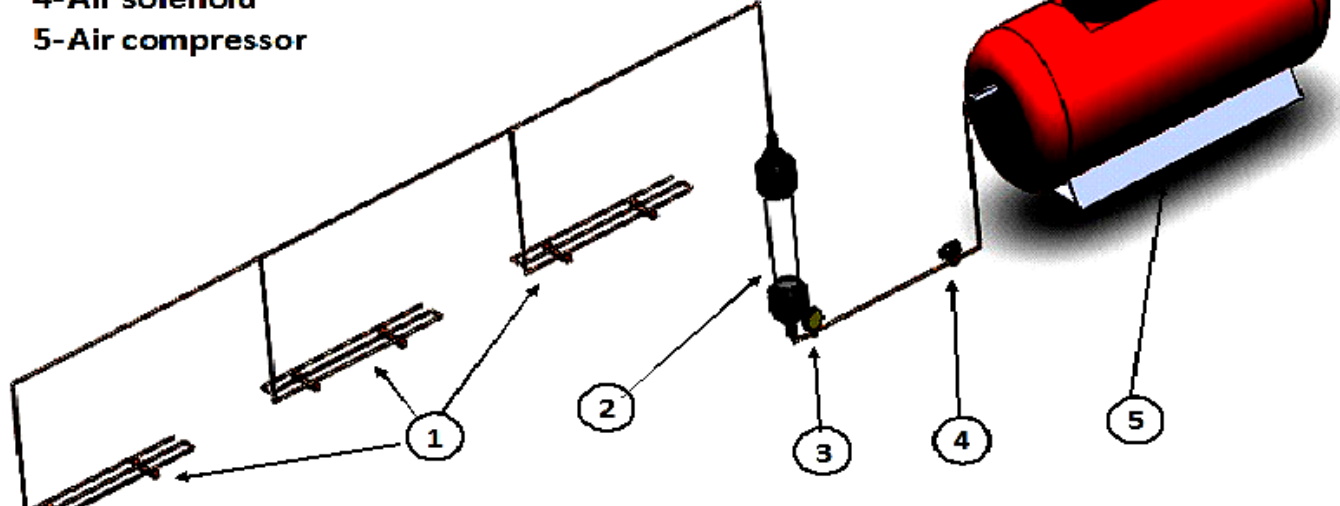

Fig. 2. Air Bubble Generation (ABG) system layout and component. 


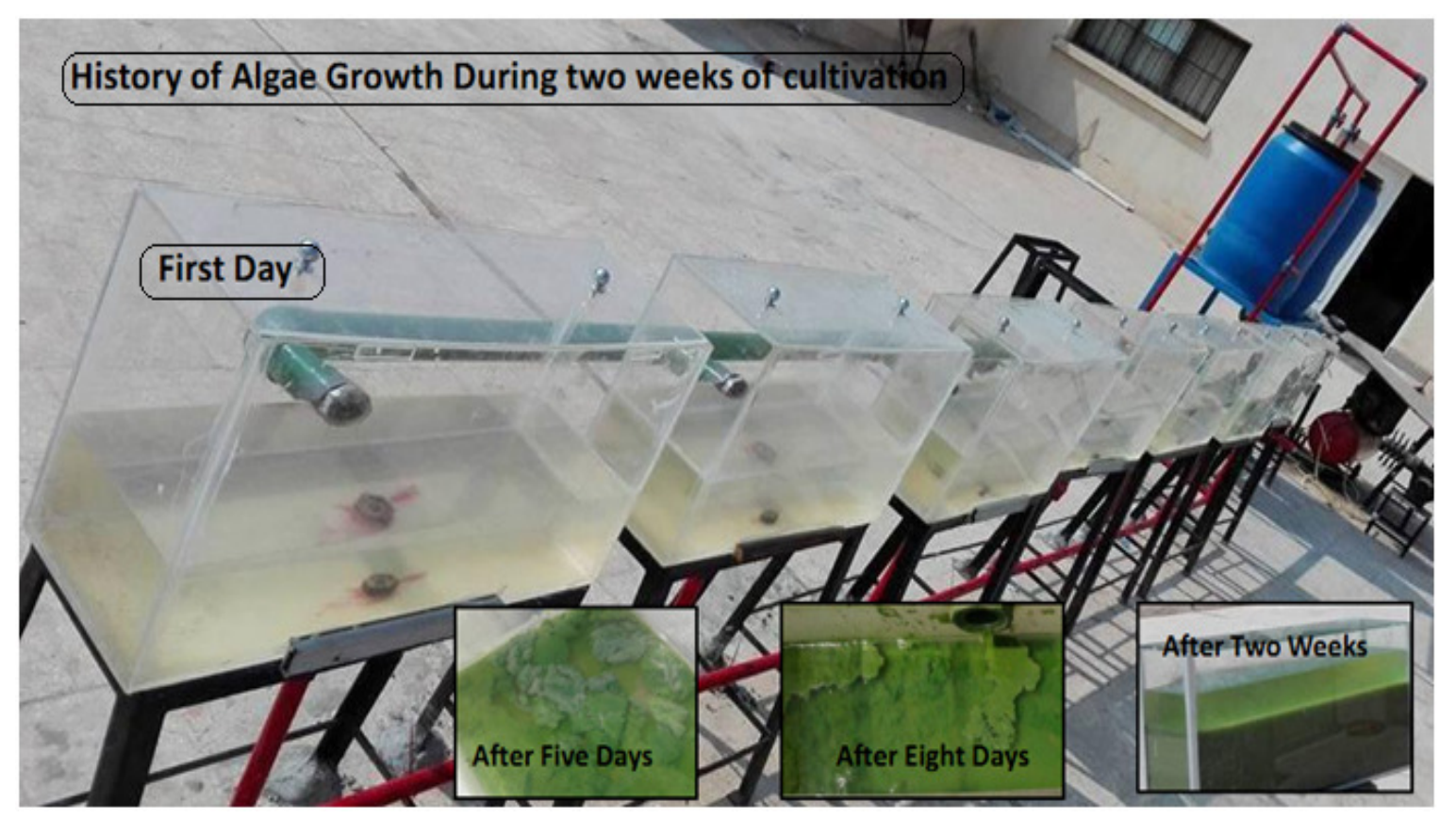

Fig. 3. Photos of the algae growth hestroy during one of the tested cultivation cycle.

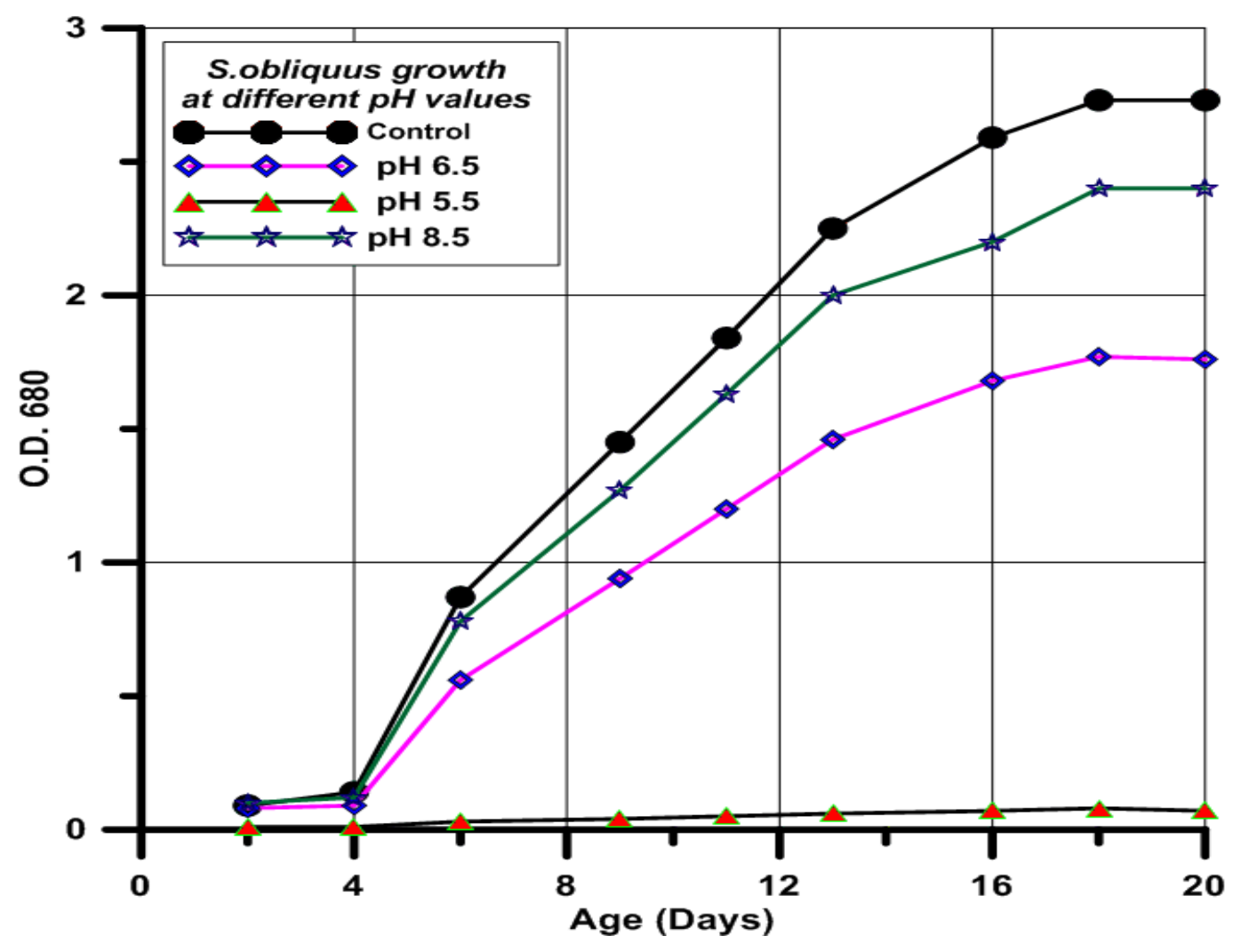

Fig. 4. Productivity at given $\mathrm{PH}$ values. 


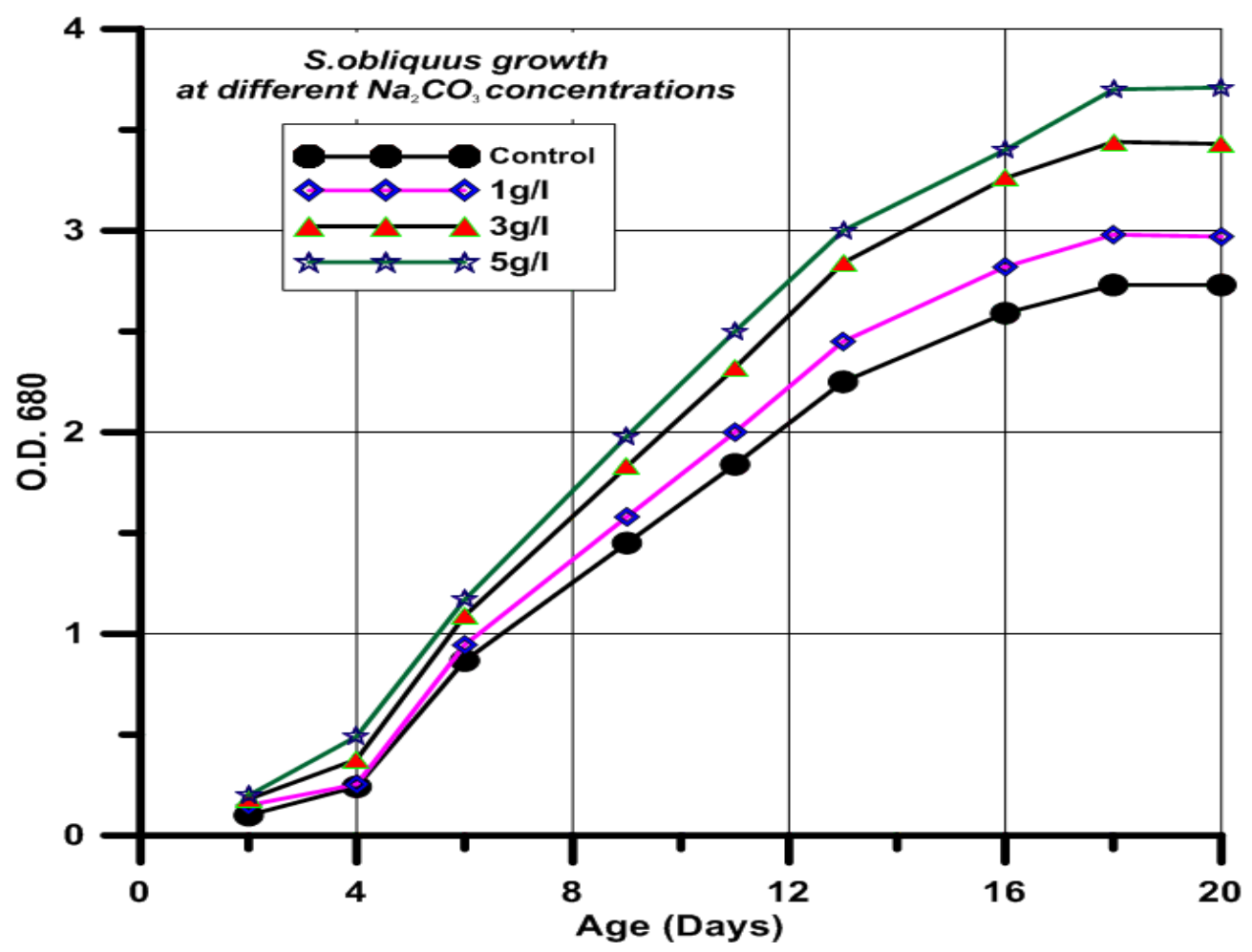

Fig. 5. Growth at $\mathrm{Na} 2 \mathrm{CO} 3$ concentrations.

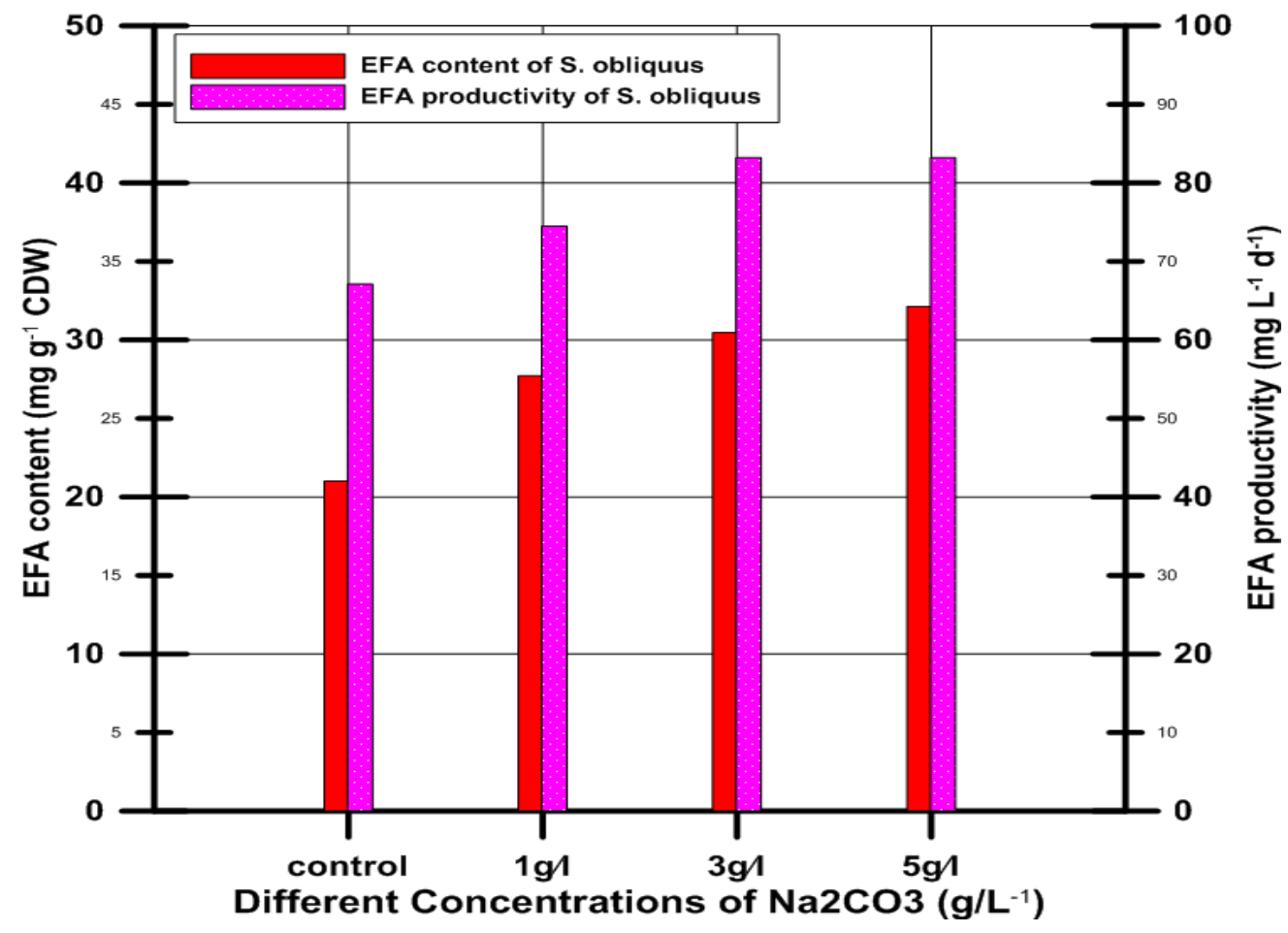

Fig. 6. EFA productivity at $\mathrm{Na} 2 \mathrm{CO} 3$ concentrations. 


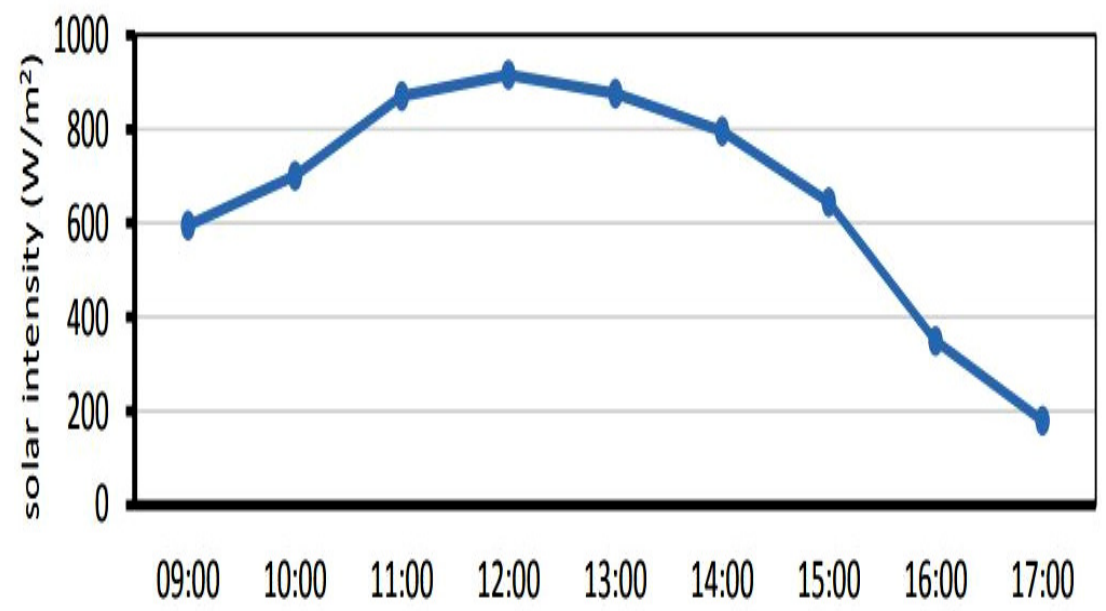

Fig. 7. Hourly variation of IR during the day of the experiment.

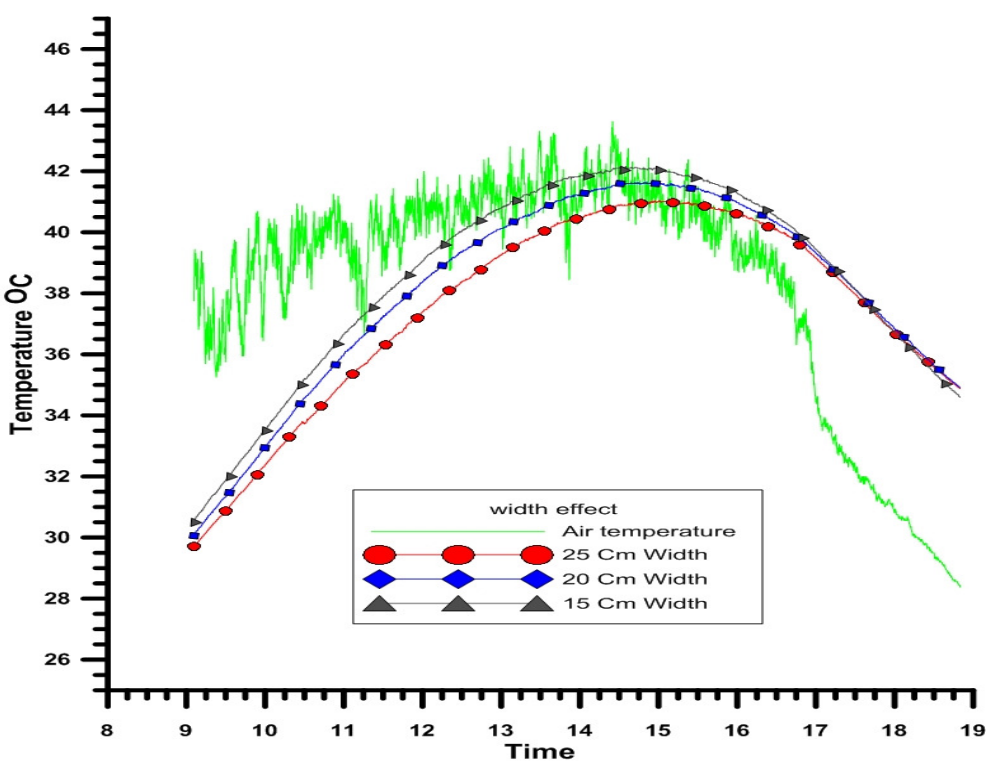

Fig. 8. Temperature variation in tanks with width.

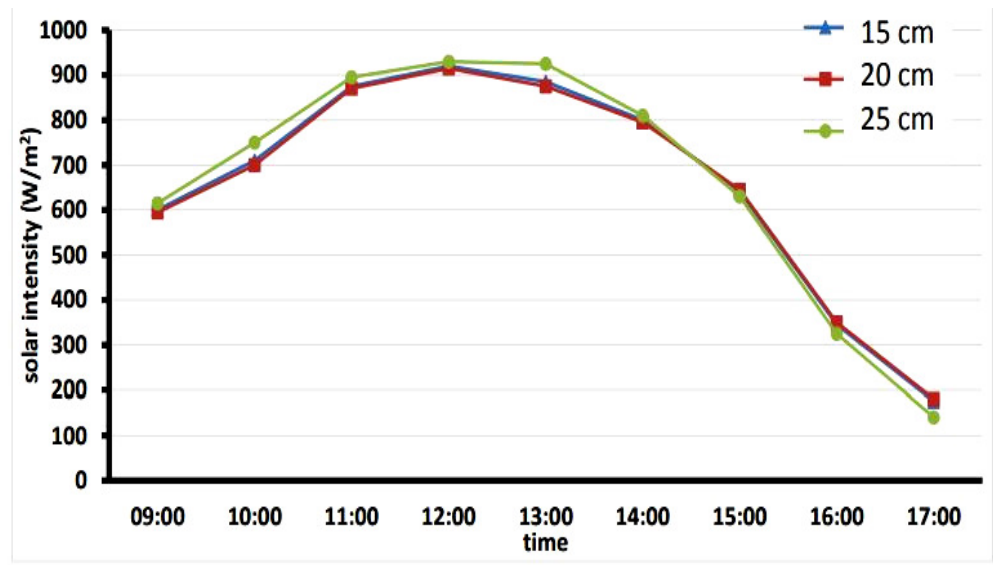

Fig. 9. Hourly variation of IR during height tests. 


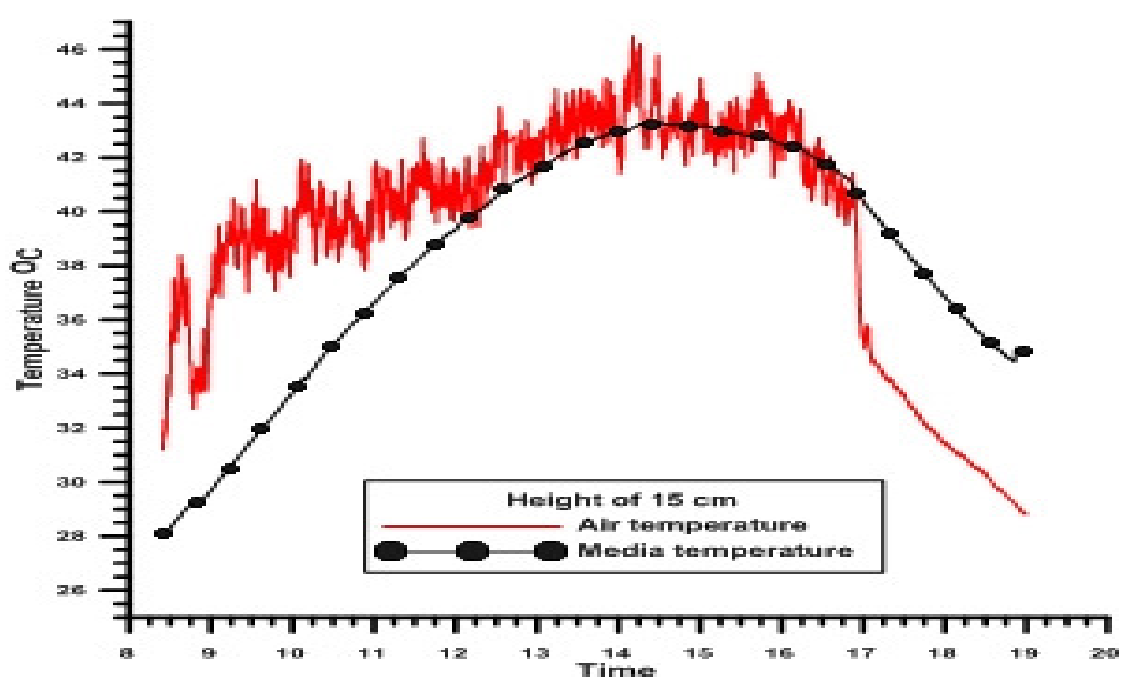

Fig. 10. Temperature variation at height of $15 \mathrm{Cm}$.

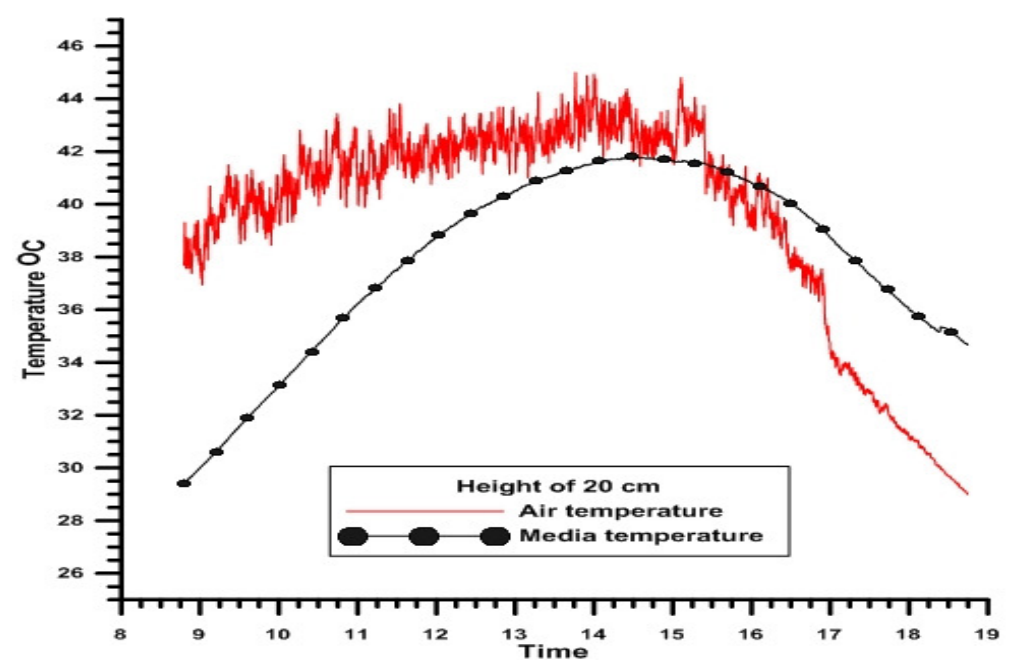

Fig. 11. Temperature variation at height of $20 \mathrm{Cm}$.

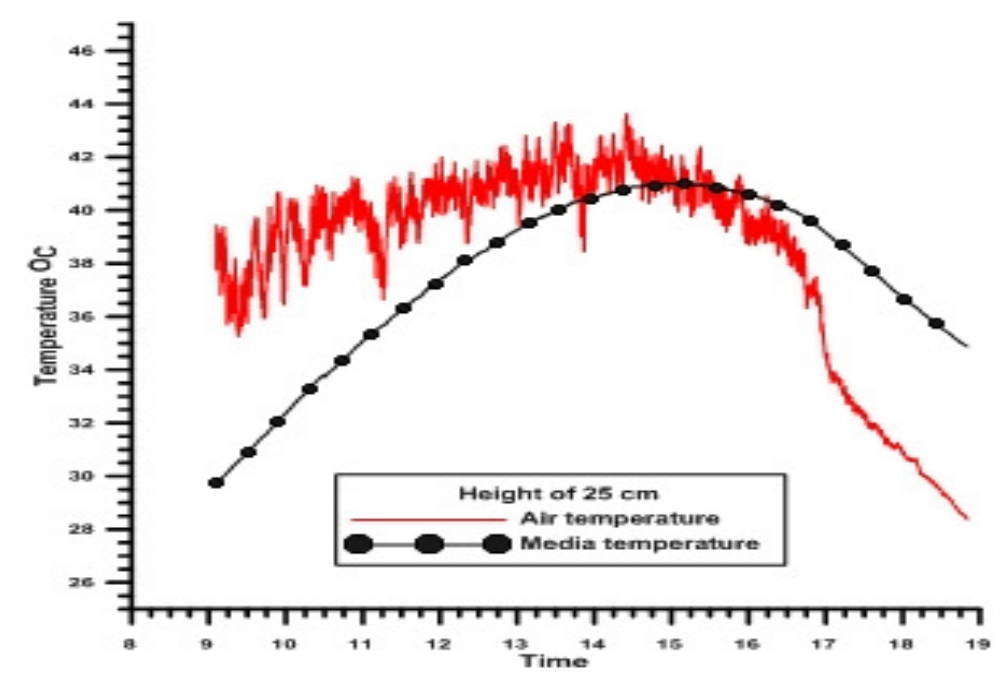

Fig. 12. Temperature variation at height of $25 \mathrm{Cm}$. 


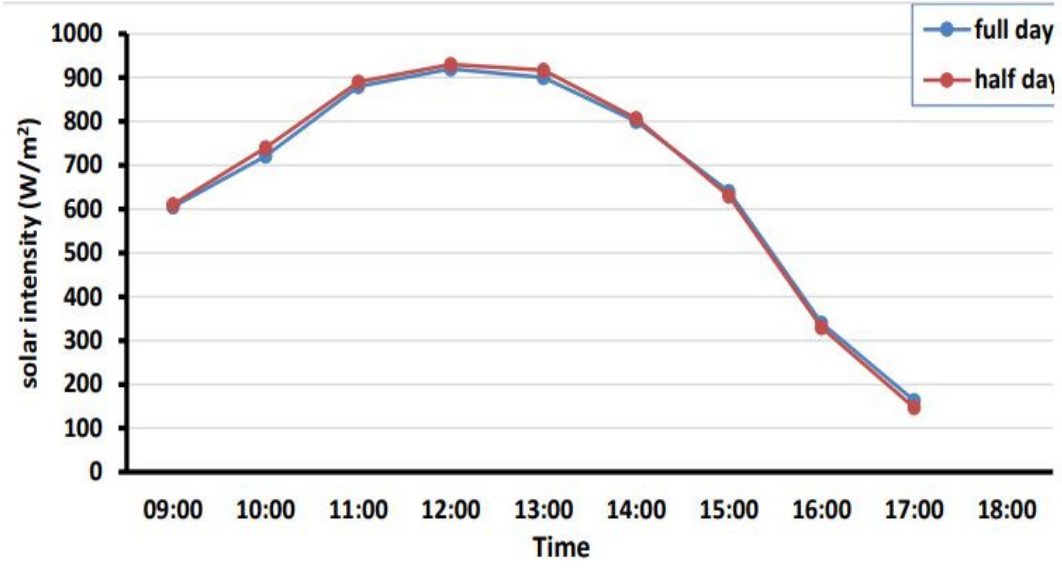

Fig. 13. Hourly variation of IR during flipping tests.

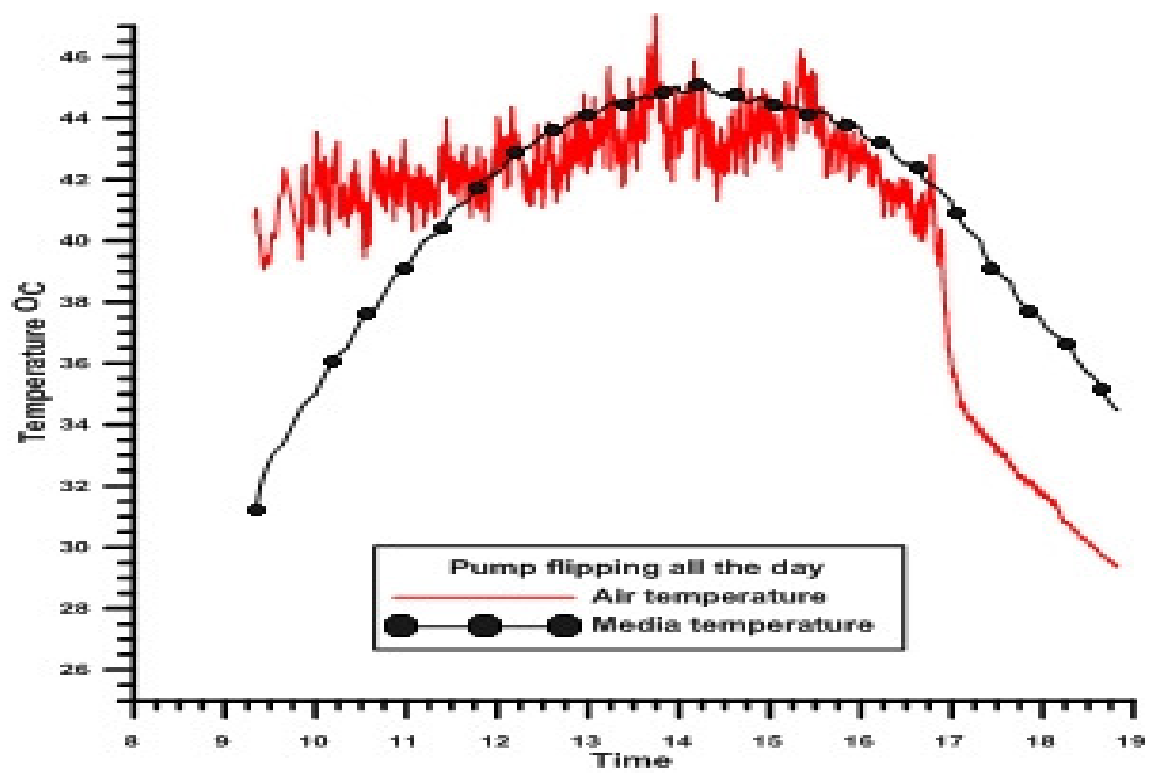

Fig. 14. Pump flipping all day.

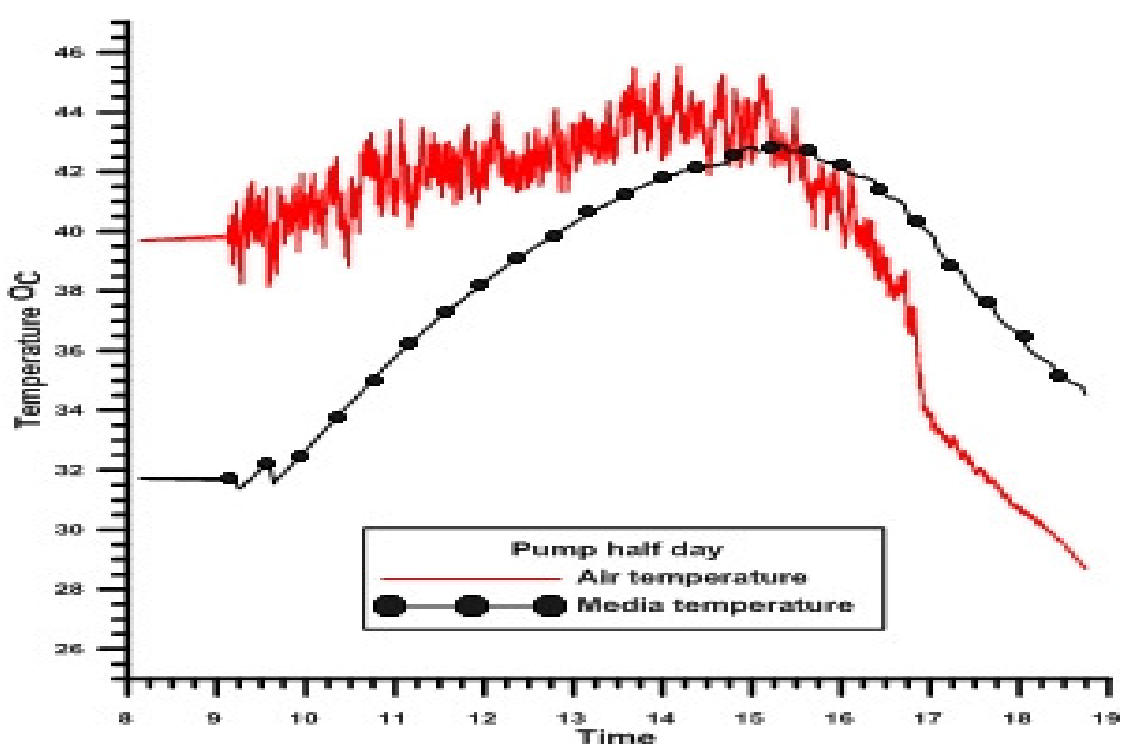

Fig. 15. Pump flipping half day. 


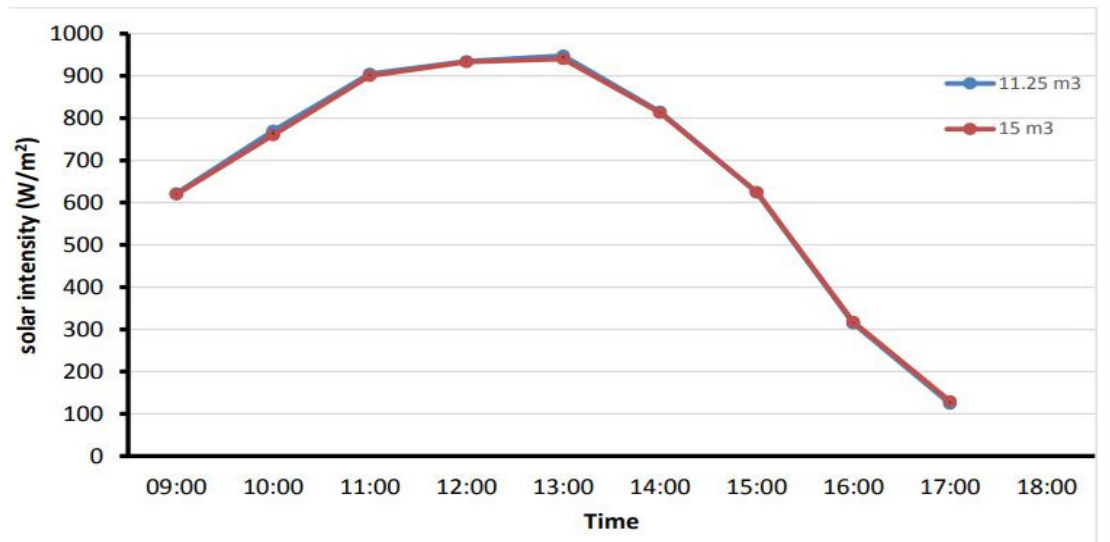

Fig. 16. Hourly variation of IR during compressed air test.

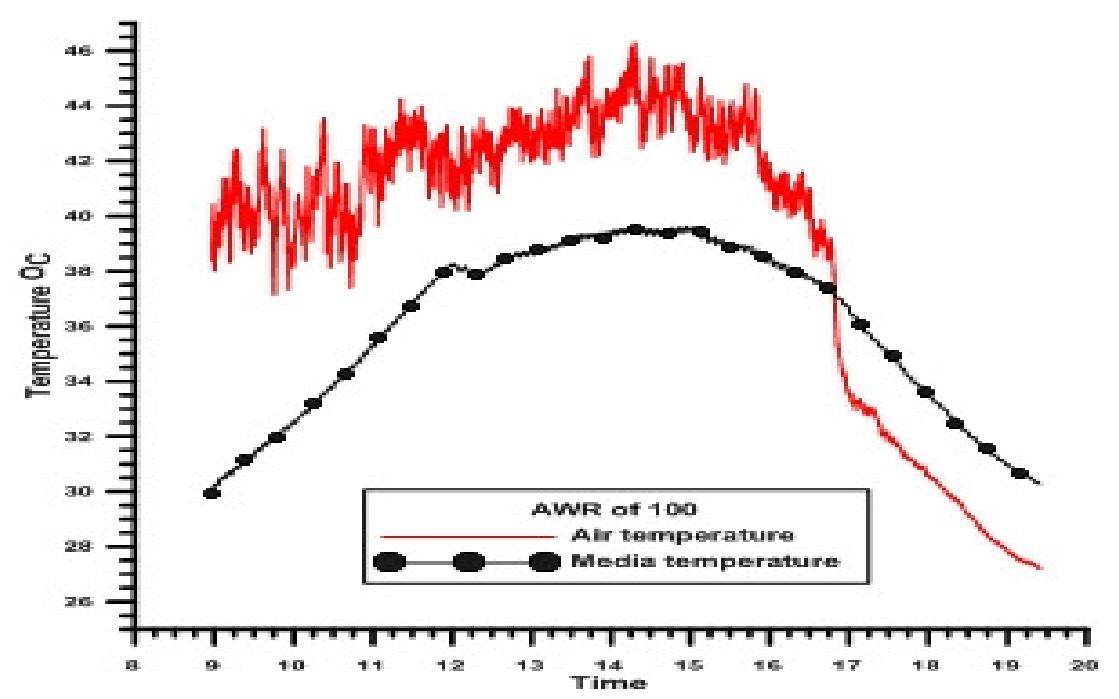

Fig. 17. Temperature variation using $A B G$ at $A W R$ of 100.

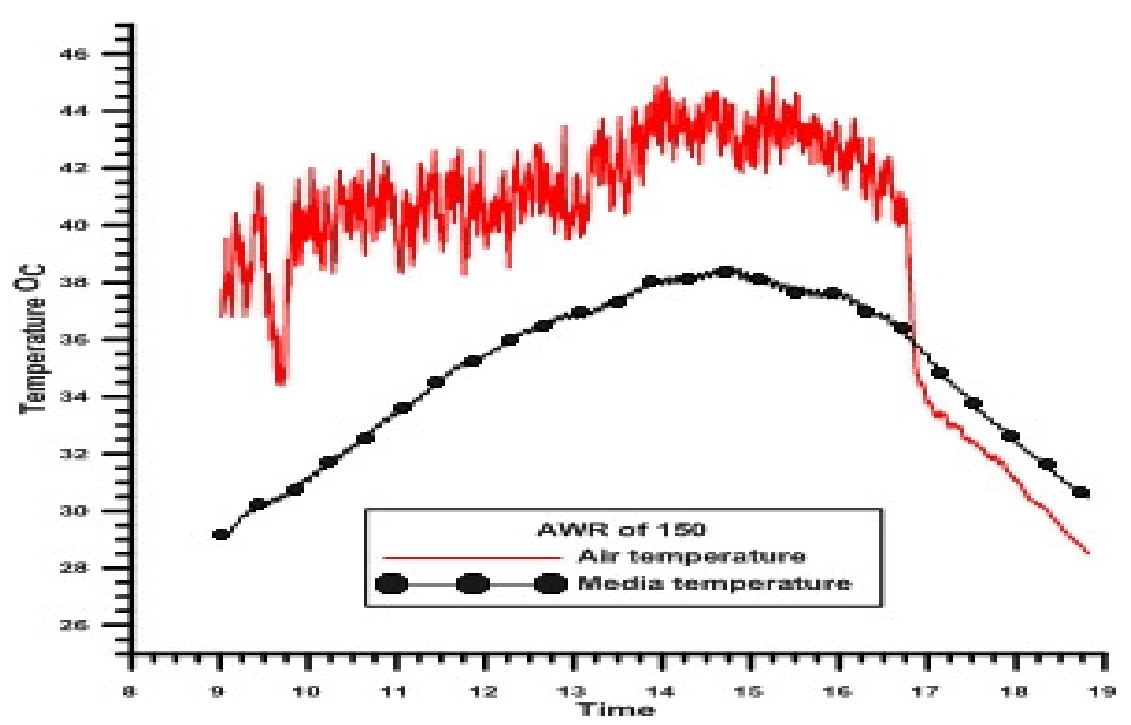

Fig. 18. Temperature variation using $A B G$ at $A W R$ of 100. 


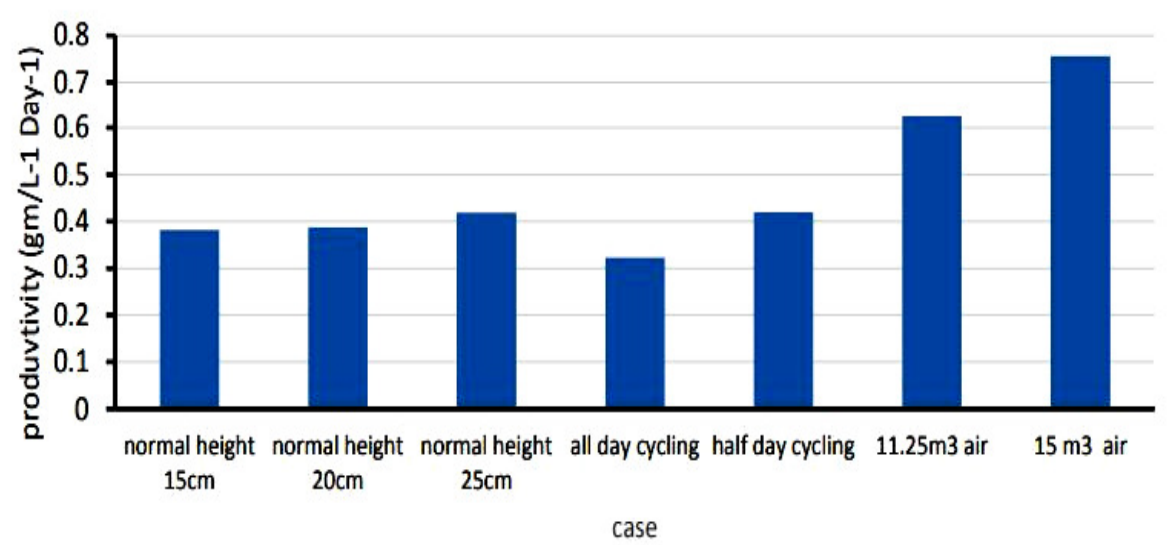

Fig. 19. Productivity of the Studed cases.

Table 1. Measurements uncertainties and relative errors.

\begin{tabular}{lll}
\hline Parameter & Uncertainty & Relative error \\
\hline Temperature $\left({ }^{\circ} \mathrm{C}\right)$ & $\pm 0.5^{\circ} \mathrm{C}$ & $1.06 \%$ \\
Solar radiation $\left(\mathrm{W} / \mathrm{m}^{2}\right)$ & \pm 2 & $0.2 \%$ \\
Air flow rate $(L P M)$ & \pm 2.35 & $2.5 \%$ \\
\hline
\end{tabular}

Table 2. Outdoor experiments

\begin{tabular}{|c|c|c|c|c|}
\hline \multirow[b]{2}{*}{ No: } & \multirow[b]{2}{*}{ Experiments } & \multirow[b]{2}{*}{ Days } & \multicolumn{2}{|c|}{ Circumstances } \\
\hline & & & Temperature & $\begin{array}{l}\text { Solar } \\
\text { radiation }\end{array}$ \\
\hline 1 & Optimum width & 1:11/June 2017 & $\begin{array}{c}\text { Max recorded } \\
\text { temperatures } \\
\left(41^{\circ} \mathrm{C} \text { to } 45^{\circ} \mathrm{C}\right)\end{array}$ & $\begin{array}{c}\text { Max recorded } \\
\text { solar intensity } \\
\left(915 \mathrm{~W} / \mathrm{m}^{2}\right)\end{array}$ \\
\hline 1 & $\begin{array}{l}\text { Ordinary at height of } \\
15 \mathrm{~cm}\end{array}$ & $\begin{array}{c}\text { 12:21/June } \\
2017\end{array}$ & $\begin{array}{c}\text { Max recorded } \\
\text { temperatures } \\
\left(39.5^{\circ} \mathrm{C} \text { to } 46.5^{\circ} \mathrm{C}\right)\end{array}$ & \\
\hline 2 & $\begin{array}{l}\text { Ordinary at height of } \\
20 \mathrm{~cm}\end{array}$ & $\begin{array}{c}\text { 23/june:2/July } \\
2017\end{array}$ & $\begin{array}{l}\text { Max recorded } \\
\text { temperatures } \\
\left(41^{\circ} \mathrm{C} \text { to } 45^{\circ} \mathrm{C}\right)\end{array}$ & $\begin{array}{c}(915 \text { to } 930 \\
\left.\mathrm{W} / \mathrm{m}^{2}\right)\end{array}$ \\
\hline 3 & $\begin{array}{l}\text { Ordinary at height of } \\
25 \mathrm{~cm}\end{array}$ & $\begin{array}{l}\text { 4:13/July } \\
2017\end{array}$ & $\begin{array}{l}\text { Max recorded } \\
\text { temperatures } \\
\left(40^{\circ} \mathrm{C} \text { to } 43^{\circ} \mathrm{C}\right)\end{array}$ & \\
\hline 4 & Pump circulating all day & $\begin{array}{l}\text { 15:24/July } \\
2017\end{array}$ & $\begin{array}{c}\text { Max recorded } \\
\text { temperatures } \\
\left(41.5^{\circ} \mathrm{C} \text { to } 47.5^{\circ} \mathrm{C}\right)\end{array}$ & $\begin{array}{l}\text { Max recorded } \\
\text { solar intensity }\end{array}$ \\
\hline 5 & $\begin{array}{l}\text { Pump circulating half } \\
\text { day }\end{array}$ & $\begin{array}{l}\text { 26/July:4/august } \\
2017\end{array}$ & $\begin{array}{c}\text { Max recorded } \\
\text { temperatures } \\
\left(41.5^{\circ} \mathrm{C} \text { to } 45.5^{\circ} \mathrm{C}\right)\end{array}$ & $\begin{array}{c}(915 \text { to } 930 \\
\left.\mathrm{W} / \mathrm{m}^{2}\right)\end{array}$ \\
\hline 6 & $\begin{array}{l}\text { Air cooling and } \\
\text { circulating at AWR of } \\
100\end{array}$ & $\begin{array}{c}\text { 6:15/August } \\
2017\end{array}$ & $\begin{array}{c}\text { Max recorded } \\
\text { temperatures } \\
\left(43^{\circ} \mathrm{C} \text { to } 46.3^{\circ} \mathrm{C}\right)\end{array}$ & $\begin{array}{l}\text { Max recorded } \\
\text { solar intensity }\end{array}$ \\
\hline 7 & $\begin{array}{l}\text { Air cooling and } \\
\text { circulating at AWR of } \\
150\end{array}$ & $\begin{array}{c}17: 26 / \text { August } \\
2017\end{array}$ & $\begin{array}{c}\text { Max recorded } \\
\text { temperatures } \\
\left(41^{\circ} \mathrm{C} \text { to } 45.2^{\circ} \mathrm{C}\right)\end{array}$ & $\begin{array}{c}(915 \text { to } 930 \\
\left.\mathrm{W} / \mathrm{m}^{2}\right)\end{array}$ \\
\hline
\end{tabular}


Table 3. Tested Cases productivities (gm. L ${ }^{-1} \cdot$ Day $\left.^{-1}\right)$.

\begin{tabular}{|c|c|c|}
\hline $\mathbf{N}$ & Experiments & $\begin{array}{l}\text { Productivity } \\
\left(\text { gm. L-1.Day }{ }^{-1} \text { ) }\right.\end{array}$ \\
\hline 1 & Ordinary at height of $15 \mathrm{~cm}$ & 0.3821 \\
\hline 2 & Ordinary at height of $20 \mathrm{~cm}$ & 0.3874 \\
\hline 3 & Ordinary at height of $25 \mathrm{~cm}$ & 0.4189 \\
\hline 4 & Pump circulating all day & 0.3230 \\
\hline 5 & Pump circulating half day & 0.4192 \\
\hline 6 & Air bubble generation at AWR of 100 & 0.6249 \\
\hline 7 & Air bubble generation at AWR of 150 & 0.7561 \\
\hline
\end{tabular}

